
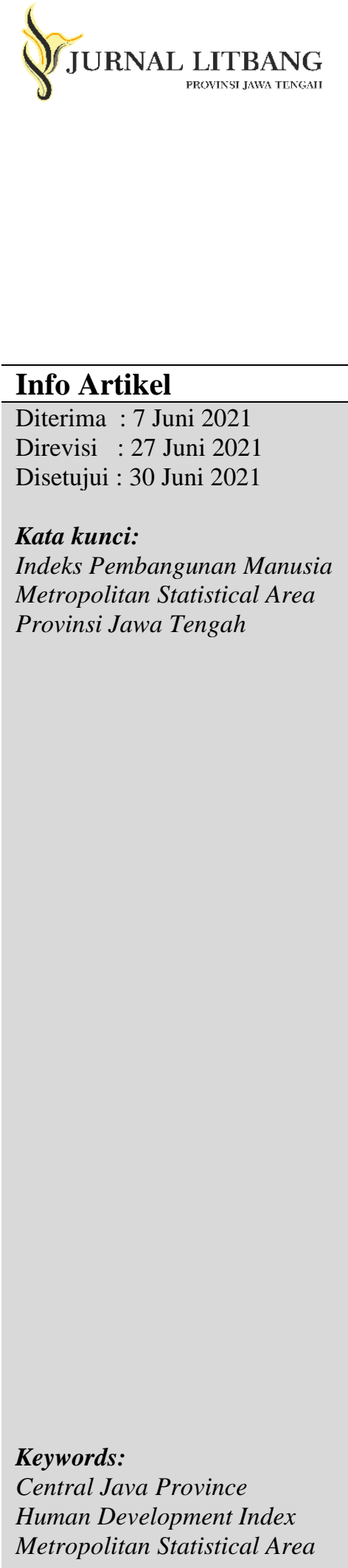

\section{Analisis Spasial: Pendekatan Metropolitan Statistical Area Untuk Perencanaan Pembangunan Manusia di Provinsi Jawa Tengah Spatial Analysis: Metropolitan Statistical Area Approach for Human Development Planning in Central Java Province}

Dian Rizqi Khusnul Khotimah

Badan Pusat Statistik Republik Indonesia

\begin{abstract}
Abstrak
Pembangunan manusia menjadi salah satu fokus utama pembangunan, yang tercantum dalam Rencana Pembangunan Jangka Menengah Nasional (RPJMN) 2020-2024. Hal tersebut tertuang pada agenda ketiga dari tujuh agenda pembangunan, yaitu "Meningkatkan Sumber Daya Manusia yang Berkualitas dan Berdaya Saing”. Tingkat pembangunan manusia pada suatu wilayah dapat tercermin melalui Indeks Pembangunan Manusia (IPM). Pada tahun 2020, IPM Provinsi Jawa Tengah bernilai 71,87. Nilai tersebut sudah termasuk pada kategori tinggi (70-80), namun IPM Provinsi Jawa Tengah masih termasuk ke rentang bawah yang lebih mendekati kategori sedang (<70). Pada tahun 2020, IPM Provinsi Jawa Tengah hanya menempati posisi ke-13 jika dibandingkan dengan 34 provinsi lainnya. Dibutuhkan pengoptimalan dalam rangka menciptakan fokus terhadap pelaksanaan program pembangunan manusia di Jawa Tengah. Pemetaan terhadap kualitas pembangunan manusia perlu dilakukan untuk memastikan pemerataan kemampuan dalam rangka meningkatkan ekonomi nasional selama masa pemulihan akibat pandemi Covid. Penelitian ini bertujuan untuk mengidentifikasi, memetakan, dan menentukan wilayah prioritas pembangunan manusia di Provinsi Jawa Tengah. Metode yang digunakan adalah analisis deskriptif, analisis spasial dengan Moran's dan LISA, serta Metropolitan Statistical Area (MSA). Variabel yang dianalisis adalah nilai IPM untuk 35 kabupaten/kota di Provinsi Jawa Tengah. Hasil analisis deskriptif menunjukkan bahwa wilayah kiri atau barat Provinsi Jawa Tengah memiliki persebaran nilai IPM yang cenderung lebih rendah. Hasil analisis spasial menunjukkan adanya keterkaitan secara geospasial yaitu antara pembangunan manusia dengan pembangunan berbasis kewilayahan. Berdasarkan analisis MSA, perencanaan pembangunan manusia di Provinsi Jawa Tengah sebaiknya difokuskan pada ketiga MSA yang terbentuk, yaitu MSA Tegal, MSA Pekalongan, dan MSA Purworejo.
\end{abstract}




Corresponding Author:
Dian Rizqi Khusnul Khotimah,
S.Tr.Stat.
dian.rizqi@bps.go.id
082324713474

\section{PENDAHULUAN}

Secara nasional, pembangunan manusia menjadi salah satu fokus utama pembangunan oleh pemerintah dalam Rencana Pembangunan Jangka Menengah Nasional (RPJMN) 2020-2024. Hal tersebut tertuang pada agenda ketiga dari tujuh agenda pembangunan, yaitu "Meningkatkan Sumber Daya Manusia yang Berkualitas dan Berdaya Saing” (Pemerintah RI, 2020).

Secara regional, Pemerintah Provinsi Jawa Tengah melalui RPJMD Tahun 20182023 juga menjadikan pendidikan dan pembangunan manusia sebagai salah satu fokus utama pembangunan. Provinsi Jawa Tengah memiliki visi "Menuju Jawa Tengah Sejahtera dan Berdikari". Salah satu strategi dan arah kebijakan yang tertuang dalam RPJMD tersebut yaitu menjadikan Sumber Daya Manusia sebagai kekuatan internal Provinsi Jawa Tengah (Pemerintah Provinsi Jawa Tengah, 2019).

Jawa Tengah menduduki posisi ke-3 sebagai Provinsi dengan jumlah penduduk tertinggi secara nasional, yaitu sebesar 36,52 juta jiwa berdasarkan hasil Sensus Penduduk 2020 (BPS, 2021). Jumlah penduduk yang besar tersebut dapat menjadi kekuatan pembangunan jika didukung dengan kualitas dan kapasitas penduduk yang baik.
Kualitas dan kapasitas penduduk pada suatu wilayah dapat dilihat melalui Indeks Pembangunan Manusia (IPM). IPM menjadi salah satu cerminan keberhasilan pencapaian tujuan dalam Sustainable Development Goals (SDGs) (Human Development Report, 2019). IPM menjadi sebuah ukuran tunggal yang mampu mengungkap kemajuan pada tiga dimensi dasar pembangunan manusia, yaitu kesehatan, pendidikan, dan standar hidup. Dengan adanya IPM, perbandingan keberhasilan capaian pembangunan manusia antarwilayah dapat dilakukan, baik secara regional, nasional, hingga internasional.

Pada tahun 2020, IPM Provinsi Jawa Tengah bernilai 71,87. Meski sudah termasuk pada kategori tinggi (70-80), namun IPM Provinsi Jawa Tengah tersebut masih termasuk ke nilai ambang batas yang lebih mendekati kategori sedang (<70). Jika dibandingkan dengan provinsi lainnya, IPM Provinsi Jawa Tengah hanya menempati posisi ke-13 di antara 34 provinsi lainnya (BPS, 2021). Sebaran nilai IPM antar kabupaten/kota di Jawa Tengah yang cenderung bervariasi menjadi penyebab belum optimalnya capaian nilai IPM di Provinsi Jawa Tengah. 
Salah satu upaya yang dapat dilakukan oleh pemerintah daerah guna mengurangi ketimpangan wilayah, yang di dalamnya juga mencakup ketimpangan pembangunan manusia adalah dengan mengadakan kerjasama pembangunan antarwilayah (Katherina, 2016). Pendekatan pembangunan berbasis wilayah (spasial) perlu dilakukan. Pendekatan spasial mampu mengurangi kesenjangan pembangunan antardaerah, meningkatkan integrasi dan efektifitas pelaksanaan pembangunan di tengah keterbatasan dana (Bappenas, 2016).

Peningkatan pembangunan manusia memerlukan upaya yang tepat dan terkoordinasi serta saling mendukung antarbidang (UNDP, 2020). Pandemi Covid19 yang berdampak terhadap hampir seluruh aspek kehidupan manusia telah menjadi tantangan tersendiri bagi pembangunan manusia di Indonesia. Percepatan pemulihan ekonomi nasional dapat berhasil apabila didukung dengan kekuatan sumber daya manusia yang berkualitas dan produktif. Pemetaan terhadap kualitas pembangunan manusia perlu dilakukan untuk memastikan pemerataan kompetensi dalam mendukung upaya percepatan pemulihan ekonomi nasional tersebut. IPM dapat menjadi ukuran yang tepat dalam memetakan kualitas pembangunan manusia berdasarkan kriteria pendidikan, kesehatan, dan ekonomi yang terkandung pada indikator IPM.

Oleh karena itu, berdasarkan latar belakang permasalahan tersebut, penelitian ini bertujuan untuk mengidentifikasi, memetakan, dan menentukan wilayah prioritas pembangunan manusia di Provinsi Jawa Tengah dengan menggunakan pendekatan Metropolitan Statistical Area (MSA). Objek yang akan diteliti adalah variabel IPM untuk setiap kabupaten/kota di Provinsi Jawa Tengah. Melalui MSA dapat dibentuk wilayah prioritas pembangunan manusia dan kewilayahan berdasarkan integrasi sosial-ekonomi di Jawa Tengah. Hasil dari penelitian ini diharapkan dapat bermanfaat sebagai rekomendasi bagi pemerintah dalam menyusun kebijakan terkait kekuatan pembangunan di Provinsi Jawa Tengah dari segi pengoptimalan Sumber Daya sesuai RPJMD 2018-2023.

\section{METODE}

Penelitian ini menggunakan data Indeks Pembangunan Manusia (IPM) di Provinsi Jawa Tengah. Data yang digunakan terdiri atas IPM untuk 35 kabupaten/kota di Provinsi Jawa Tengah pada tahun 2020. Data tersebut diperoleh dari Badan Pusat Statistik Provinsi Jawa Tengah (BPS Jateng, 2020).

Metode analisis data yang digunakan adalah analisis deskriptif, analisis spasial, dan analisis Metropolitan Statistical Area (MSA). Analisis deskriptif dilakukan dengan menggunakan peta tematik. Peta tematik mampu menyajikan serta memvisualisasikan data secara lebih menarik dan lebih mudah dipahami (Tennekes, 2018). Pada penelitian ini, peta tematik akan digunakan untuk melihat persebaran capaian IPM antarkabupaten/kota.

Analisis spasial dilakukan dengan pengecekan autokorelasi spasial. Autokorelasi spasial dapat digambarkan sebagai ada tidaknya keterkaitan antara lokasi dengan kemiripan karakteristik, yaitu kondisi ketika lokasi yang saling berdekatan memiliki pengaruh lebih besar dibandingkan dengan wilayah yang lokasinya berjauhan. (Getis, 2009). Pengecekan autokorelasi spasial dilakukan melalui dua tahap, yaitu autokorelasi spasial global melalui Global Moran's Index dan autokorelasi spasial lokal melalui Moran's Scatterplot dan Local Indicator of Spatial Association (Anselin, 2018).

Autokorelasi spasial global melalui Global Moran's Index merupakan autokorelasi yang menggambarkan hubungan yang terjadi di seluruh wilayah observasi secara umum (Scrucca, 2005). Nilai I yang positif menunjukkan terjadinya pengelompokan wilayah dengan karakteristik yang sama, sedangkan nilai I yang negatif menunjukkan pengelompokkan wilayah dengan karakteristik yang berbeda. 
Nilai I mendekati nol menunjukkan tidak terjadi keterkaitan antarwilayah (Bustaman dkk, 2013). Autokorelasi spasial lokal digunakan untuk pengukuran keterkaitan spasial yang lebih mendetail, misalnya kecenderungan pengelompokan wilayah (spatial clustering) hingga mendeteksi wilayah yang berbeda di antara wilayah sekitarnya (spatial outliers) (Bustaman dkk, 2013). Moran's Scatterplot digunakan untuk memperoleh gambaran kestabilan pola spasial lokal, serta Local Indicator of Spatial Association dipakai untuk menguji signifikansi pola spasial yang terbentuk (Anselin, 2018).

Secara umum, konsep dari Metropolitan Statistical Area (MSA) adalah suatu area yang terdiri dari wilayah inti beserta wilayah sekitarnya yang memiliki integrasi sosial-ekonomi yang tinggi dengan wilayah inti (OMB, 2015). Pada perkembangannya, MSA dapat digunakan untuk pembentukan wilayah prioritas sebagai dasar pengalokasian dana, pembentukan kebijakan, dan implementasi berbagai program pemerintah (OMB, 2015). Berdasarkan hal tersebut, maka pada penelitian ini, MSA akan dimodifikasi sesuai penelitian terkait, yaitu untuk menentukan wilayah prioritas pembangunan manusia di Provinsi Jawa Tengah.

\section{HASIL DAN PEMBAHASAN}

Analisis deskriptif, berupa peta tematik, bertujuan untuk melihat persebaran capaian IPM antarkabupaten/kota di Provinsi Jawa Tengah pada tahun 2020. Warna yang semakin gelap menunjukkan nilai karakteristik IPM yang semakin tinggi (baik).

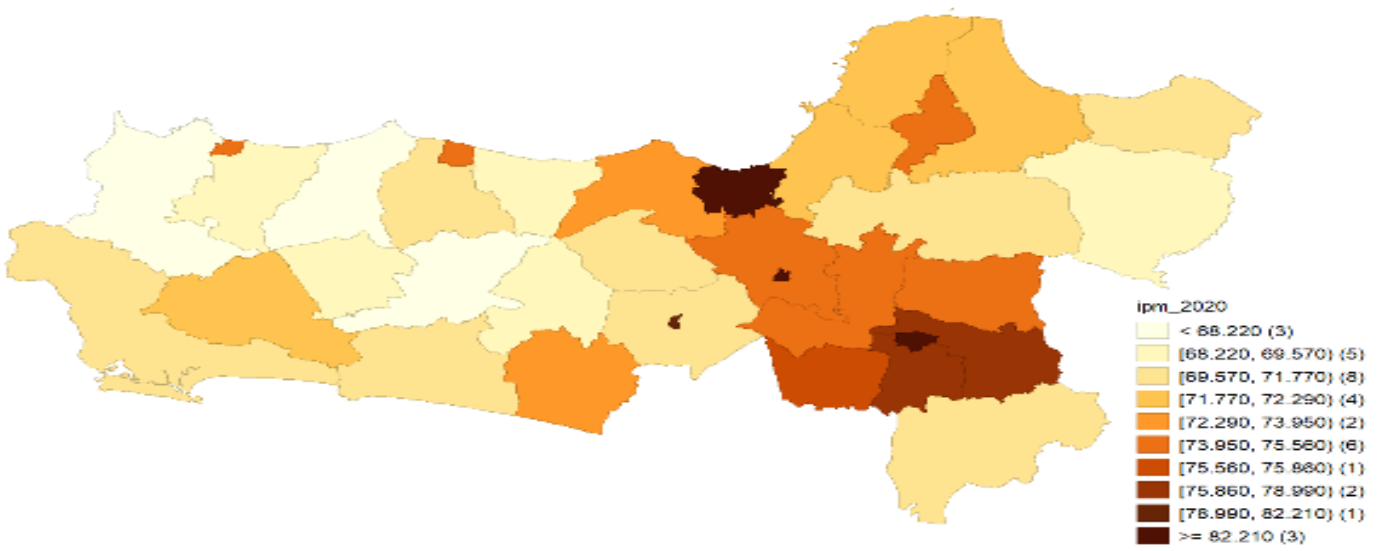

Gambar 1. Persebaran Capaian IPM Menurut Kabupaten/Kota di Provinsi Jawa Tengah Tahun 2020 (Sumber : Pengolahan data)

Berdasarkan Gambar 1, terlihat bahwa pola sebaran nilai IPM di Provinsi Jawa Tengah tahun 2020 masih didominasi oleh kabupaten/kota dengan nilai IPM menengah $(<70)$. Nilai IPM terendah dimiliki oleh Kabupaten Brebes, yaitu sebesar 66,11. Tiga IPM tertinggi diraih oleh Kota Salatiga $(83,14)$, Kota Semarang $(83,05)$, dan Kota Surakarta (82,21). Ketiga kota ini telah mampu mencapai kategori sangat tinggi (>80). Hal tersebut menunjukkan bahwa masih terjadi ketimpangan atau ketidakmerataan dalam pembangunan manusia antarkabupaten/kota di Provinsi Jawa Tengah. Data rinci mengenai nilai IPM per kabupaten/kota di Provinsi Jawa Tengah tahun 2020 dapat dilihat pada lampiran 1. 


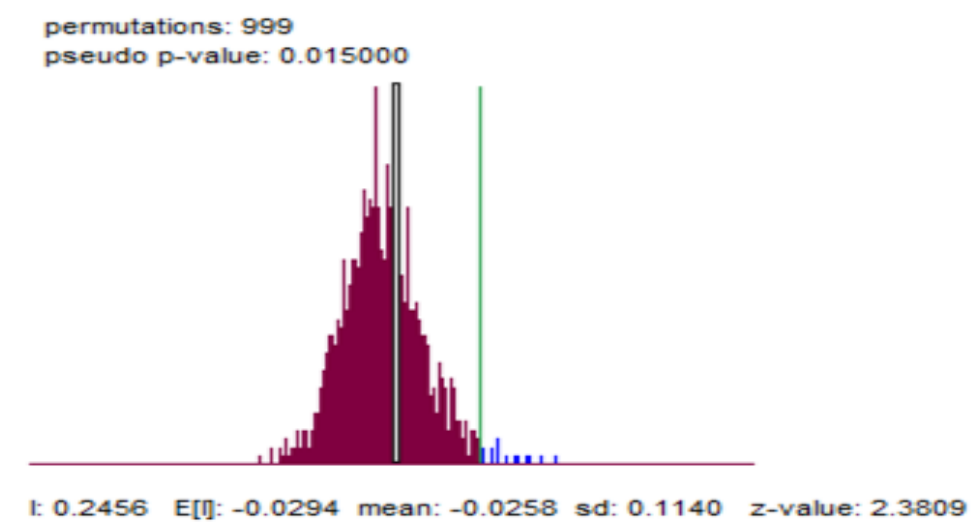

Gambar 2. Autokorelasi Global IPM Kabupaten/Kota di Jawa Tengah, 2020 (Sumber:

Pengolahan Data)

Analisis spasial diawali dengan yang didapatkan signifikan pada taraf uji (alfa pengecekan autokorelasi global untuk mengetahui ada tidaknya pengaruh spasial pada IPM di Provinsi Jawa Tengah. Berdasarkan hasil pengolahan data (Gambar 2), diperoleh nilai Global Moran's I sebesar 0,2456 , sehingga dapat disimpulkan bahwa terjadi autokorelasi spasial pada IPM di Provinsi Jawa Tengah. Artinya, terjadi saling keterkaitan antarwilayah kabupaten/kota di Provinsi Jawa Tengah berdasarkan nilai IPMnya.

Nilai dari Statistik Global Moran's I $=10 \%$, dengan nilai pseudo $\mathrm{p}$-value $=0,015$ pada permutasi sebanyak 999 kali. Nilai Global Moran's I yang positif menunjukkan terjadinya autokorelasi spasial positif yaitu berupa pengelompokan lokasi yang mempunyai nilai karakteristik IPM serupa.

Selanjutnya, pengecekan autokorelasi spasial lokal dilakukan untuk mengetahui pola spasial dari IPM di Provinsi Jawa Tengah dan mengidentifikasi kabupaten/kota mana saja yang berkelompok secara spasial.

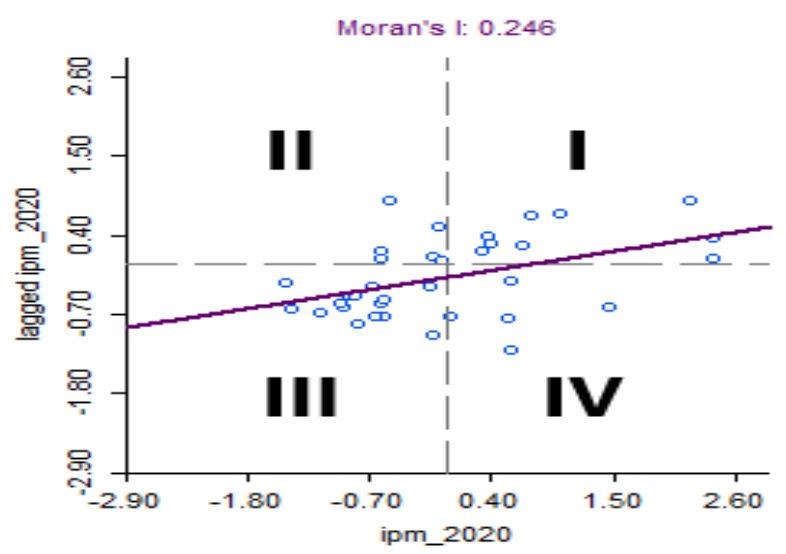

Gambar 3. Moran's Scatterplot untuk IPM di Provinsi Jawa Tengah, 2020 (Sumber: Pengolahan Data)

Pada Gambar 3, metode Moran;s scatterplot digunakan untuk mengetahui pola pengelompokan IPM secara spasial. Moran's scatterplot tersebut menunjukkan bahwa sebagian besar kabupaten/kota di Provinsi Jawa Tengah berada pada kuadran I dan II. Hal tersebut menunjukkan adanya autokorelasi spasial positif (sejalan dengan nilai Global Moran's I yang diperoleh pada tahapan analisis sebelumnya).

Terdapat beberapa kabupaten/kota yang berada pada kuadran II dan IV (spatial outliers). Agar diperoleh visualisasi pola spasial yang lebih jelas, maka hasil Moran's Scatterplot diubah menjadi peta tematik pada Gambar 4. 


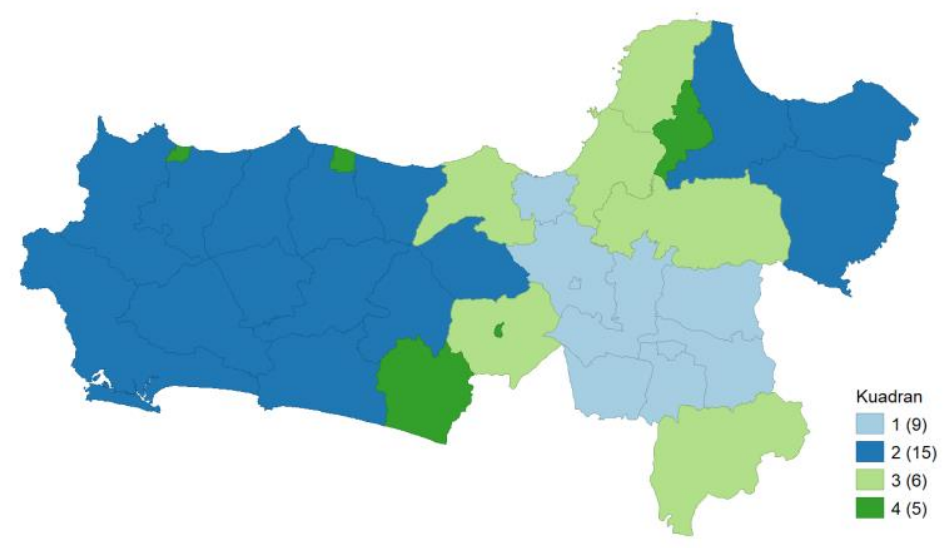

Gambar 4. Klasifikasi Kabupaten/Kota berdasarkan Kuadran Moran's Scatterplot di Provinsi Jawa Tengah, 2020 (Sumber: Pengolahan Data)

Berdasarkan Gambar 4 tersebut, terlihat dengan jelas bahwa terjadi pengelompokkan wilayah berdasarkan nilai IPM di Provinsi Jawa Tengah. Hal tersebut dapat dilihat dari kabupaten/kota pada masing-masing kuadran yang cenderung berdekatan satu sama lain.
Berdasarkan klasifikasi daerah menurut kuadran pada Gambar 4, selanjutnya dilakukan proses identifikasi daerah hotspot dan coldspot dengan menggunakan LISA cluster map.

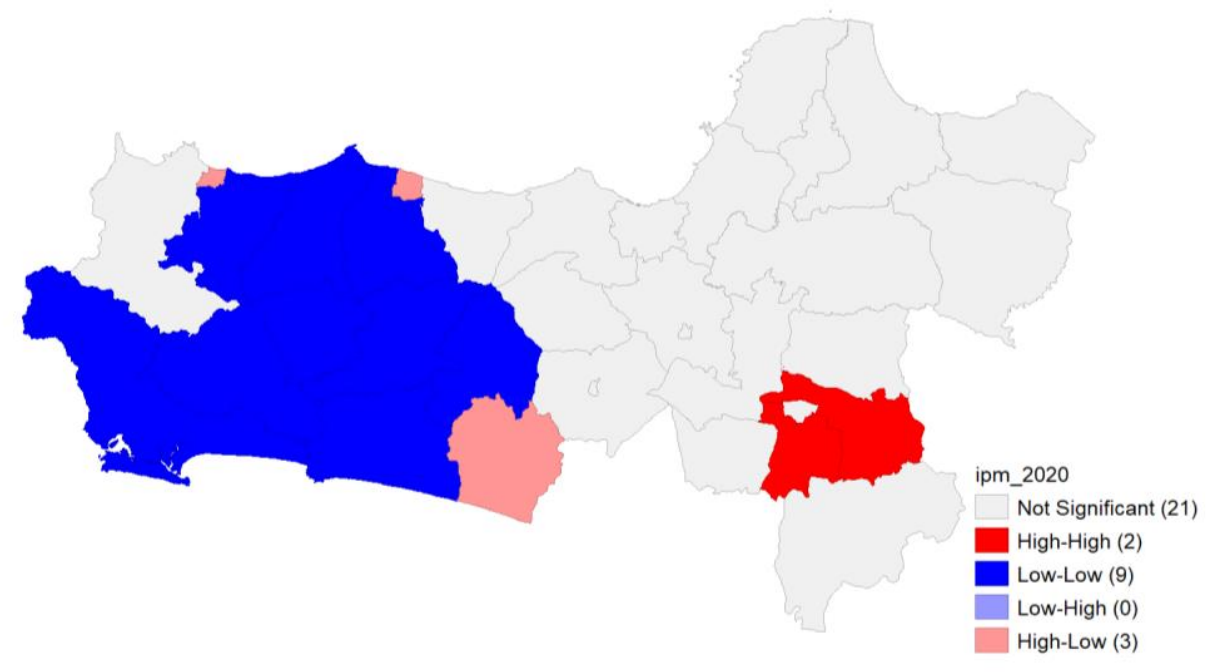

Gambar 4. LISA Cluster Map untuk IPM di Provinsi Jawa Tengah, 2020

Berdasarkan Gambar 5, teridentifikasi dua titik hotspot (High-High) yaitu Kabupaten Karanganyar dan Kabupaten Sukoharjo. Artinya, terjadi pengelompokkan kabupaten/kota dengan nilai IPM tinggi di sekitar Kabupaten Karanganyar dan
Kabupaten Sukoharjo, yang mencerminkan bahwa pembangunan telah berhasil dilakukan di wilayah tersebut dan wilayah sekitarnya.

Dapat dilihat pula bahwa terdapat 9 titik coldspot (Low-Low) yang terdapat di sisi barat atau kiri dari Provinsi Jawa Tengah. 
Selain itu, terdapat tiga wilayah yang termasuk kategori spatial outliers (HighLow), yaitu Kota Tegal, Kota Pekalongan, dan Kabupaten Purworejo. Kriteria high-Low menunjukkan bahwa ketiga wilayah tersebut memiliki IPM relatif tinggi dibandingkan wilayah sekitarnya.

Berdasarkan wilayah hotspot, coldspot, dan spatial outliers yang telah teridentifikasi, selanjutnya dilakukan analisis Metropolitan Statistical Area (MSA). MSA tersebut diadaptasi dari OMB. MSA akan dibentuk berdasarkan LISA cluster map untuk menentukan wilayah-wilayah prioritas perencanaan pembangunan manusia (Muliawan dan Ismartini, 2018).

Kabupaten/kota yang menjadi prioritas pembangunan manusia adalah kabupaten/kota dengan capaian IPM yang rendah. Central county/core merupakan kabupaten/kota dengan capaian IPM yang relatif lebih tinggi dari wilayah di sekitarnya. Hal ini diidentifikasi berdasarkan kategori High-Low pada LISA cluster map. Outlying county merupakan kabupaten di sekitar core yang memiliki hubungan sosial ekonomi yang tinggi dengan core.

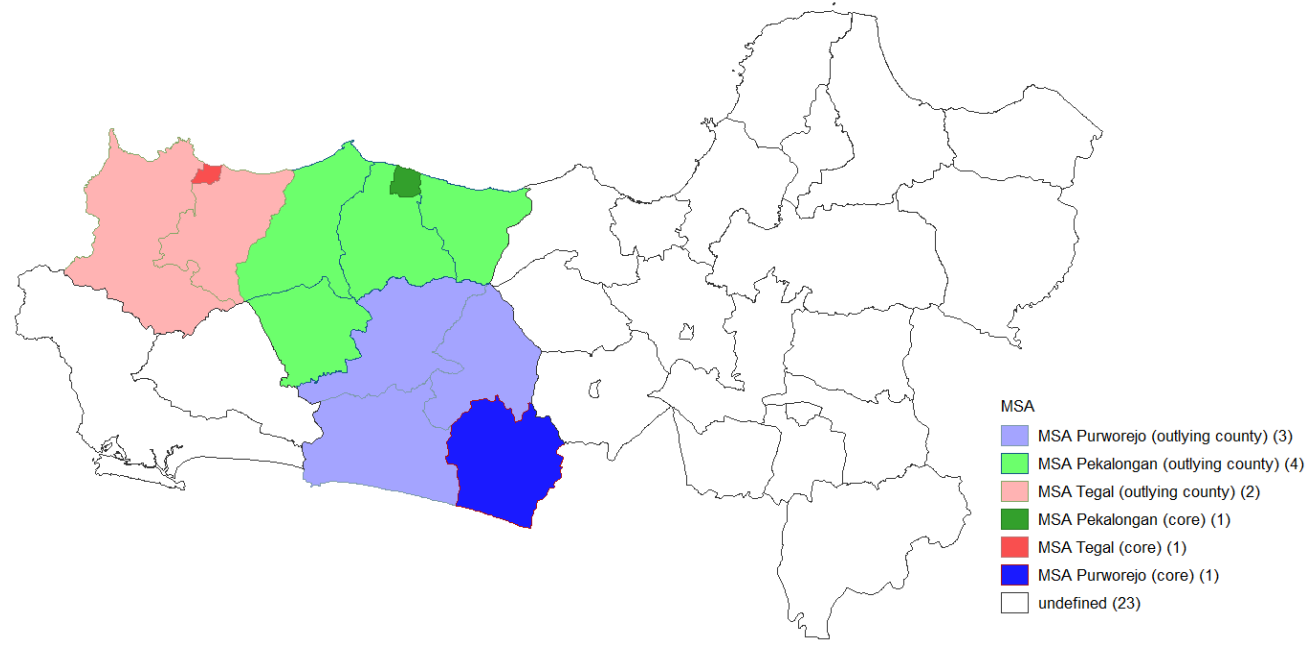

Gambar 6. MSA yang Terbentuk

Pada penelitian ini, terbentuk 3 MSA (Gambar 6) yang merupakan wilayahwilayah prioritas pembangunan manusia. Pertama, yaitu MSA Tegal. MSA tersebut terdiri atas Kota Tegal sebagai central county/core, serta 2 kabupaten lainnya sebagai outlying county, yaitu Kabupaten Brebes dan Kabupaten Tegal.

Kedua, yaitu MSA Pekalongan. MSA tersebut terdiri atas Kota Pekalongan sebagai central county/core, serta 4 kabupaten lainnya sebagai outlying county, yaitu Kabupaten Pemalang, Kabupaten Pekalongan, Kabupaten Batang, dan Kabupaten Purbalingga.
Ketiga, yaitu MSA Purworejo. MSA tersebut terdiri atas Kabupaten Purworejo sebagai central county/core, serta 3 kabupaten lainnya sebagai outlying county, yaitu Kabupaten Kebumen, Kabupaten Banjarnegara, dan Kabupaten Wonosobo.

Jika dilihat dari variabel pembentuk IPM, ketiga MSA yang terbentuk ini cenderung memiliki karakteristik pendidikan yang masih terbatas jika dibandingkan wilayah lain di Provinsi Jawa Tengah. Padahal, penguatan pada sektor pendidikan dapat berkontribusi dalam membentuk karakter, kompetensi, dan keahlian sumber daya manusia. Hal ini akan berimplikasi 
secara simultan dalam meningkatkan kualitas dan kuantitas hasil pekerjaan, produktivitas, sehingga kesejahteraan ekonomi yang diperoleh pun semakin baik.

Oleh karena itu, terbentuknya ketiga MSA tersebut, diharapkan dapat menjadi rekomendasi bagi pemerintah dalam menyusun kebijakan pembangunan manusia, khususnya pendidikan yang tepat guna mewujudkan kesejahteraan dan kekuatan pembangunan di Provinsi Jawa Tengah, yang sejalan dengan upaya pengoptimalan Sumber Daya, sesuai RPJMD 2018-2023.

\section{SIMPULAN}

Berdasarkan hasil dan pembahasan sebelumnya, dapat ditarik beberapa kesimpulan. Pertama, pola sebaran IPM menunjukkan bahwa Provinsi Jawa Tengah masih didominasi oleh kabupaten/kota dengan nilai IPM yang menengah ke bawah $(<70)$. Wilayah sisi barat atau kiri dari Provinsi Jawa Tengah memiliki sebaran nilai IPM yang cenderung lebih rendah.

Kedua, sebagai perencanaan pembangunan, terdapat tiga wilayah prioritas pembangunan manusia yang terbentuk, yaitu MSA Tegal, MSA Pekalongan, dan MSA Purworejo. MSA Tegal terdiri atas Kota Tegal sebagai central county/core, serta 2 kabupaten sebagai outlying county (Brebes dan Tegal). MSA Pekalongan terdiri atas Kota Pekalongan sebagai core, serta 4 kabupaten sebagai outlying county (Pemalang, Pekalongan, Batang, dan Purbalingga). MSA Purworejo terdiri atas Kabupaten Purworejo sebagai core, serta 3 kabupaten sebagai outlying county (Kebumen, Banjarnegara, dan Wonosobo).

\section{SARAN}

MSA Tegal, MSA Pekalongan, dan MSA Purworejo merupakan area dengan kualitas pembangunan manusia yang masih kurang dan terpilih menjadi wilayah prioritas pembangunan manusia di Provinsi Jawa Tengah. Terbentuknya ketiga MSA tersebut dapat menjadi rekomendasi bagi pemerintah Provinsi Jawa Tengah dalam menghasilkan berbagai kebijakan yang lebih tepat terkait dengan pembangunan manusia di Provinsi Jawa Tengah. Agar kebijakan pembangunan manusia di Provinsi Jawa Tengah dapat langsung menyentuh akar dari masalah, maka segala bentuk kebijakan dan program terkait pembangunan manusia dapat dikonsentrasikan pada MSA Tegal, MSA Pekalongan, dan MSA Purworejo.

Sebagai bentuk inovasi dalam percepatan pembangunan manusia sekaligus pembangunan kewilayahan, pada setiap MSA, perlu diterapkan mekanisme kerjasama pentahelix yang mengintegrasikan antara akademisi, dunia bisnis, pemerintah, media, dan masyarakat. Akademisi akan berperan sebagai tim riset potensi sosial ekonomi wilayah, dunia bisnis sebagai pendukung pembiayaan dan proses bisnis, pemerintah sebagai regulator, media sebagai sarana promosi, serta kontribusi masyarakat sebagai pendukung suksesnya keberlangsungan program.

Selanjutnya, tiap MSA akan ditransformasi menjadi pusat pengembangan keahlian-keahlian spesifik tertentu sekaligus pusat-pusat produk ekonomi tertentu. Pembangunan sebuah sistem informasi terpadu berbasis web dapat digunakan untuk menunjang proses implementasi program mulai dari sosialisasi, pelatihan keahlian, pengajuan inovasi, pembentukan UMKM dan sentra produksi, pameran, penjualan produk, sarana diskusi, dan sebagainya. Agen transformasi dari setiap desa/kelurahan yang terdiri atas akademisi dan masyarakat setempat perlu dibentuk untuk mengawal keberhasilan implementasi program, termasuk pendampingan penggunaan sistem.

\section{DAFTAR PUSTAKA}

Anselin, Luc. 2018. Local Spatial Autocorrelation (1), Common Univariate Local Statistics. https://geodacenter.github.io/workbook /6a_local_auto/lab6a.html\#principle. (5 Juni 2021)

Badan Perencanaan Pembangunan Nasional. 2016. Buletin Kawasan: Menuju Perencanaan Berbasis Kawasan. Jakarta: Bappenas. Edisi 27. 
Badan Pusat Statistik Provinsi Jawa Tengah (BPS Jateng). 2021. Data Indeks Pembangunan Manusia 2018-2020. https://jateng.bps.go.id/indicator/26/83/ 1/indeks-pembangunan-manusiametode-baru-.html. (6 Juni 2021)

Badan Pusat Statistik (BPS). 2021. Indeks Pembangunan Manusia 2020. Jakarta: BPS RI.

Badan Pusat Statistik. 2021. Hasil Sensus Penduduk 2020. Jakarta: BPS RI.

Bustaman, U. dkk. 2013. Penggunaan Metode Geographically Weighted Regression (GWR) untuk Analisis Data Sosial dan Ekonomi. Jakarta: BPS.

Federal Register. 2000. Standards for Defining Metropolitan and Micropolitan Statistical Area. Office Management and Budget. Vol 65, No. 249.

Getis, Arthur. 2009. Handbook of Spatial Analysis. United State of America: Springer Science Business Media.

Human Development Report. 2019. Human Development and the SDGs. New York: UNDP.

Katherina, R.D. 2016. Kebutuhan Kerjasama Antar Daerah dalam Pembangunan Wilayah. https://kependudukan.lipi.go.id/kajiankependudukan/kebutuhan-kerjasamaantar-daerah-dalam-pembangunanwilayah/. (4 Juni 2021)

Muliawan, R. H. A. and Ismartini, P. 2018. Perencanaan Pembangunan Manusia di Provinsi Papua Menggunakan Pendekatan Metropolitan Statistical Area dan Regresi Spasial. STIS.

Office Management and Budget. 2015. Revised Delineations of Metropolitan Statistical Areas, and Combined Statistical Areas, and Guidance on Uses of the Delineations of These Areas. [Bulletin]. OMB Bulletin. No. 15-01.

Pemerintah Provinsi Jawa Tengah. 2019. Perda Provinsi Jawa Tengah Nomor 5
Tahun 2019 tentang Rencana Pembangunan Jangka Menengah Daerah Provinsi Jawa Tengah Tahun 2018-2023. Semarang: Pemerintah Provinsi Jawa Tengah.

Pemerintah RI. 2020. Perpres RI Nomor 18 Tahun 2020 tentang Rencana Pembangunan Jangka Menengah Nasional 2020-2024. Jakarta: Pemerintah RI.

Scrucca, L. 2005. Clustering Spatial Multivariate Data Based on Local Measures of Spatial Autocorrelation, An Application to Labor Market in Umbria. [Research paper]. Department of Economic, Finance and Statistics.

Tennekes, M., 2018. tmap: Thematic Maps in R. Journal of Statistical Software, 84(6), pp.1-39.

United Nations Development Programme. 2020. Human Development Perspectives: Covid 19 And Human Development: Assessing the Crisis, Envisioning the Recovery. New York: UNDP. 
